\title{
Fools, jesters and the possibility of responsible leadership
}

\begin{abstract}
The vibrant academic and practitioner conversation about corporate responsibility does not appear to reduce the number of scandals involving unethical managerial behaviour. This leaves a question of whether responsible organisational leadership is possible. Some leadership scholars recently suggested that understanding leadership as a relational process can facilitate more responsible leadership practice. This paper develops the relational leadership perspective by offering a critical discussion of the possibility of responsible relational leadership. I construct an understanding of responsibility following the writings of Emmanuel Levinas and Jacques Derrida. I then use the archetypal figure of the Fool as an imagination device to translate Levinasian and Derridian ethics into lived experiences and thus illuminate the conditions under which responsibility may be possibilised. This theoretical analysis exposes the irresolvable tension between responsibility and the relational in leadership, rendering responsible leadership unreachable as an end goal. At the same time, it suggests that leadership actors can strive for responsibility by engaging with the tension between responsibility and the relational, namely through seeking out liminal experiences and being open to the dangers associated with both liminality and responsibility.
\end{abstract}

Key words: responsible leadership, aporia, Levinas, Derrida, the Fool, archetypes 


\section{Introduction}

The aim of this paper is to explore the conditions of possibility of responsible leadership. The notions of leadership and responsibility and ethics are entwined in academic thought about leaders and leadership. When we say 'leader', we usually mean someone who, at the very minimum, strives to lead her followers to some form of positive achievement (Jackson and Parry, 2011; Peters and Austin, 1985). When the leader does not fulfil this expectation, her leadership credentials are questioned and a different label is often attached to her - e.g. a tyrant, a despot (Kociatkewicz and Kostera, 2012). Researchers also associate unethical leadership with negative outcomes for both organisations and followers (Arjoon, 2000; Aronson, 2001; De Hoogh and den Hartog, 2008; Sims and Brinkmann, 2002, 2003), and some identify particular leadership discourses - for instance, the notion of leadership as emanating from an individual who influences others from an autonomous position - as ethically deficient (Gemmill and Oakley, 1992; Wray-Bliss, 2013). Either way, 'the study of ethics is fundamental to the study of leadership' (Ciulla, 2012: 508) and researchers and practitioners alike ask what ethical leadership is and how it can be achieved.

An important feature of the current ethical/responsible leadership literature is a diversity of theoretical perspectives. Some focus on leaders' personal characteristics and virtues (e.g. Avolio et al., 2004; Bass and Steidlmeier, 1999; Molyneaux, 2003). Others view leadership as a relational process and focus on how leaders may or may not discharge their responsibilities to their followers, organisations and other stakeholders (Jones, 2014; Pless and Maak, 2011). Yet others critique the discourse of leadership as a function and feature of select individuals and promote its understanding as an intersubjective, relational process, as constructed and enacted within organisational communities through intersecting meaning, knowledge and skill contributions by many organisational members (Cunliffe and Erisken, 2011; Gronn, 2000; Sutherland et al., 2014). The relational perspectives in particular contain a 
powerful promise of more responsible leadership through emphasising the responsibilities of leaders to others and pointing out the democratising potential of recognising leadership as a communal process.

In this paper, I specifically seek to contribute to the development of the relational leadership perspective. I will understand leadership as 'occurring in embedded experience and relationships' (Cunliffe and Erisken, 2011: 1429, original emphasis) between many 'leadership actors' or individuals who construct and exercise leadership 'by managing meaning, defining reality and providing a basis for organizational action' (Sutherland et al., 2014: 764). While I acknowledge the potential of the relational understanding to promote responsible leadership, my key aim is to suggest that the embeddedness of leadership actors into relational structures also limits responsible action. More optimistically, I will argue that the recognition of this very limitation is precisely what creates the conditions for possibility of responsibility in leadership.

I propose that responsible leadership should be understood as an experience of an aporia or a paradoxical situation where contradictory notions seemingly coexist (Derrida, 1993). This proposition is based on a multi-disciplinary perspective. First, following other leadership scholars such as Knights and O’Leary (2006) and Rhodes (2012), I will use the writings of Emmanuel Levinas to understand ethics as responsibility to the Other. I will supplement this understanding with writings of Jacques Derrida, particularly his The Gift of Death that is explicitly devoted to the notion of ethics as responsibility and, in some ways, takes the thinking of Levinas further. Specifically, I rely on Derrida's treatment of aporia as a necessary condition for the possibility of responsibility (Derrida, 2008).

Second, I will use a Jungian psychoanalytic perspective and draw on the archetypal figure of the Fool as an imagination device that would allow me to identify the relational processes that constitute leadership as a limit of responsibility. Jungian archetypes, as well as 
myths, legends and literary works in which they feature, have been used by management scholars to understand contemporary organisations and contemporary society (e.g. Gabriel, 2004; Kostera, 2008, 2013) and leadership in particular (Abramson, 2007; Hatch and Kostera, 2004; Kociatkewicz and Kostera, 2012). I will show the Fool to be a figure who, through the combination of liminality, radical creative potential and danger contained in her $^{1}$, represents a partial lived embodiment of Levinasian and Derridian ethics of responsibility. Examining the various aspects of this embodiment will allow me to suggest that to strive for responsibility, the leadership actor would need to transgress the relational processes and networks that make her leadership possible. The dissolution of leadership will, paradoxically, emerge as a condition for the possibility of responsible leadership.

\section{Leadership as a relational process}

Literature on ethical and responsible leadership is diverse. One influential perspective sees responsible leadership as emanating from a figure of an individual leader. Leaders are said to create and sustain ethical and unethical organisational cultures (Grojean et al., 2004; Ofori, 2009; Sims and Brinkmann, 2003; Wu et al., 2015). A related perspective attempts to define the individual features of an ethical leader. A leader's ethical standing is equated with 'authenticity' or a diverse set of virtues such as altruism, sincerity, honesty, confidence, optimism, resilience and a keen awareness of the others' needs and perspectives (Avolio et al., 2004; Bass and Steidlmeier, 1999; also see Ford and Harding, 2011 for a critical review). 'Reverence' - a deep awareness of one's own limitations - and 'meekness' are also suggested as pre-conditions for the ethical exercise of power (Molyneaux, 2003; Woodruff, 2001).

\footnotetext{
${ }^{1}$ The Fool is an androgynous figure, capable of being both male and female and of shifting between the sexes. While she is most often presented in myths and stories as male, in this paper I will use the female pronoun to refer to her to highlight her androgyny and avoid more cumbersome linguistic constructions such as "he/she" and "they". I will employ the male pronoun only when discussing specifically male manifestation of the Fool (e.g. the Fool in King Lear).
} 
Other leadership ethics researchers explore leadership as a process as opposed to a set of individual characteristics and actions. Brown, Trevino and Harrison (2005: 120), for instance, define ethical leadership as 'the demonstration of normatively appropriate conduct'. Other organisational members and the broader environment have an input in constructing a situational understanding of ethical leadership. This processual and contextualised view is linked to the increasingly prominent systemic and relational understandings of leadership that challenge the conceptualisation of leadership as an objective feature of individual agency. Scholars in this area use a variety of terms - e.g. systemic, distributed, shared, relational, collective, emergent, etc. leadership - pursue different agendas and come from different disciplines. Some of these perspectives argue that, even when a formal leader is recognised, she is discursively constructed and enabled as such by the organisational community. For instance, organisational members may reify particular persons in leader roles by projecting their own anxieties onto them (Gemmill, 1992; 2002). Writers also observe that leadership is a 'social process' or 'group quality' (Bolden, 2011: 252) with influence, skills and expertise distributed, exchanged and pooled within a network of interacting actors (Bennett et al., 2003; Gronn, 2000; Spillane and Diamond, 2007). Others attempt to move away from theorising based on the leader-follower dynamic and demonstrate the possibility of leadership as constructed and exercised through collective and egalitarian meaning-making (e.g. Sutherland et al., 2014). While these perspectives are diverse, they are united by a critique of the conceptualisation of leadership as a universally intelligible feature of individual agency produced by a specific set of individual traits. Leadership is understood as the relational dayto-day practice "whereby "leadership" is conceived of as a collective social process emerging through the interaction of multiple actors' (Bolden, 2011: 251; see also Cunliffe and Eriksen, 2011; Gronn, 2000; Uhl-Bien, 2006). 
The relational takes on leadership are sometimes explicitly normative. Some researchers advocate the deliberate sharing out of leadership activity within an organisation to achieve a variety of organisational outcomes and debate how this can be done (e.g. Harris et al., 2007; Wang et al, 2014). Others note the potential of distributed and/or leader-less leadership to democratise organisational relationships, bring hidden violence to critical attention and support responsible organising (Jones et al., 2016; Pearce et al., 2014; Sutherland, Land and Böhm, 2014).

Some writers within the relational leadership literature encourage conceptualisation of leadership as relationship with, responsibility for and accountability to others inside and outside the organisation (Cunliffe and Eriksen, 2011; Gabriel, 2014; Rhodes, 2012). Such writings often draw on the philosophy of Emmanuel Levinas who approached ethics as a relational mode of existence and as responsibility to others. Jones (2014) goes as far as to define being a leader as being responsible for others (also see Gond et al., 2011; Maak and Pless, 2006; Pless and Maak, 2011; Rhodes, 2012; Wray-Bliss, 2013). Knights and O’Leary (2006) suggest that the preoccupation with leaders' characteristics (e.g. leaders' authenticity) may inadvertently reinforce unethical practice. These approaches encourage leaders to focus on their own personas as opposed to their relationships with and responsibilities to and for others. Knights and O'Leary (2006) offer Levinas's conceptualisation of ethics as response to the Other that is prioritised over the concern about own characteristics and image.

I will understand leadership as a relational process where leadership is socially constructed and performed by a collective of 'leadership actors' within a particular organisational context (Sutherland et al., 2014: 764). I will also acknowledge the Levinasian strand of the relational leadership literature and its suggestion that the possibility of ethical leadership lies in leadership actors prioritising their responsibilities to others. The key message, however, will be to reveal a tension between the notions of leadership as produced 
and performed in a particular relational organisational context and ethical leadership as responsibility to others. The rest of the paper is devoted to the exposition of this tension and its implications.

The first sign of this tension is already present in the Levinasian perspective within the relational strand of the responsible leadership literature. I use the next section to bring it to the forefront of the conceptualisation of responsibility, developing this theme further through the ethical writings of Jacques Derrida.

\section{Responsibility as the (im)possible}

The philosophy of Emmanuel Levinasian has been widely used in organisation studies to critique the conceptualisations of organisational ethics and responsibility as codifiable, subject to management control, and grounded in the logic of rational calculation (Bevan and Corvellec, 2007; Pullen and Rhodes, 2015). Such conceptualisations are particularly prevalent in the discussions of Corporate Social Responsibility that emphasise creation of codes of conduct, social responsibility reporting, measurement of responsibility-related 'performance', and management oversight and transparency of organisational activities. As the main focus of these approaches is not organisational stakeholders but the organisational itself, its image and its internal processes, they end up prioritising corporate social legitimacy and enabling selfserving conduct (Banerjee, 2008; Rhodes, 2016; Roberts, 2003).

Levinas's (e.g. 1985a; 1989) understanding of ethics is characterised by the focus on the 'Other' as opposed to the self and a refusal to create universally applicable guidelines for ethical behaviour. Levinas's task is one of 'trying to find the meaning of ethics' (Jones, 2003: 228), and the meaning is found not in the character of the actor, as in virtue ethics, or in the outcomes of an act, as in teleological ethics, or the form of the act, as in deontological ethics, but in the moment when the self faces the Other. Ethics for Levinas is foremost about how 
one relates to others. Jones, Parker and ten Bos (2007) write that others can be used as means to particular ends or, at best, treated the same as self, denying them an independent subjectivity. Even when the independence and difference of others is acknowledged, it can be ignored, meaning it does not cause any corresponding change in the self to accommodate it. The ethical for Levinas only becomes possible when others are treated as Others (the capital ' $\mathrm{O}$ ' denoting their importance), implying an openness to change in oneself to accommodate the difference of the Other. Crucially, the response to the Other must not carry an expectations of positive return for the self as that would fold the impulse and the action back onto the self, reducing the Other to the self (Levinas, 1985b).

Levinas's understanding of responsibility contains an aporia. First, as existence is not possible without encountering and so occupying intersecting paths with the Other in some way; the self is 'taken hostage' (Van de Ven, 2005: 8). Responsibility cannot be assumed, it is always there, irrespective of one's actual response to the Other or even the awareness of the Others' existence. The Other can also never be fully known. The alterity of the other does not have boundaries and refuses total understanding. It is never fully accessible through the sensemaking categories available to the self.

The face is present in its refusal to be contained. In this sense it cannot be comprehended, that is, encompassed. It is neither seen nor touched - for in visual or tactile sensation the identity of the I envelops the alterity of the object, which becomes precisely a content. ... The face resists possession, resists my powers. (Levinas, 2011/1961: 194-197).

As the infinite alterity of the Other problematizes the use of own pre-understandings in formulating the response, all pre-set conceptions of ethical action (e.g. ethical charters, codes of conduct, established norms) fail to amount to responsibility (Levinas, 1978/1997). 
The impossibility of fully knowing the Other is the source of the constant impasse between the impossibility to view the word from the perspective of the Other and the need to respond to the demands that are issued from that inaccessible position. An inescapable violence towards the Other arises when one has no choice but to respond to the Other from the position of reduction (Levinas, 2011/1961).

The aporia present in Levinas's responsibility means that responsibility is not a way to security that can be derived from a sense of internal coherency and stability and from the certainty about the outcomes of one's actions. In Levinas's ethics of responsibility, the self is constantly undermined and destabilised. The unknowable nature of the Other precludes any certainty about the Other's motivations or the outcomes of responding to his/her calls. Thus, responsibility is never finalised.

In the Gift of Death (2008), Derrida also writes of responsibility as response to the Other. Ethics is not about a 'transcendental objective' but about 'the relation to the other' (p. 51). The response to the Other also must be a gift, i.e. it must not be based on an expectation of reciprocation. Even aiming for a particular outcome for the Other would negate the gift as this would involve an assessment conducted from the perspective of the self. A responsible decision is thus never a case of simply following rules or weighing the outcomes and always involves uncertainty:

...if decision-making is relegated to a knowledge that it is content to follow or to develop, then it is no more a responsible decision; it is the technical deployment of a cognitive apparatus, the simple mechanistic deployment or a theorem (p. 26).

Absence of concrete reference points and impossibility of relying on existing rules and norms injects uncertainty and danger into the exercise of responsibility. One can never be assured that her attempts at responsibility will actually amount to responsibility. The certainty of 
responsibility within responsibility is lacking. Thus, responsibility again is an experience of an aporia. However, it is the recognition of the impossibility of responsibility that allows us to discern its possibility, however unreachable. 'An aporia will thus not be synonymous with closure but will instead represent a limit through which something announces itself in an affirmative fashion' (Raffoul, 2008: 272).

Derrida develops the theme of aporia further. As the self and what is known to self cannot serve as a knowledge base for decisions about the response to the Other, responsibility is always potentially transgressive and diverging from known precepts and norms. Moreover, the use of speech threatens responsibility as language is a knowledge system that bends subjectivity to the convention of the day, and so its use threatens the reduction of the infinite and unknowable Other to the pre-existing understandings. As a result,

The exercise of responsibility seems to leave no choice but this one, however uncomfortable it be, of paradox, heresy, and secrecy. More serious still, it must always run the risk of conversion and apostasy: there is no responsibility without a dissent and inventive rupture with respect to tradition, authority, orthodoxy, rule, or doctrine. (p. 29)

Further in the Gift of Death, Derrida uses the story of Abraham's sacrifice of Isaac to illustrate the experience of such responsibility: Abraham readies himself to sacrifice his beloved son Isaac in response to the demand from God - the ultimate unknowable Other. He does so silently, without speaking to his community. Paradoxically, in his ethical response to God, Abraham breaks accepted ethical norms and becomes a murderer in all but the act:

The ethical can therefore end up making us irresponsible. It is a temptation, a tendency, or a facility that would sometimes have to be refused in the name of a responsibility that 
doesn't keep account or give an account, neither to man, to humans, to society, to one's fellows, or to one's own. (p. 62)

Abraham's responsibility is an embrace of aporia, a 'leap beyond knowledge' (Raffoul, 2008: 285).

Derrida also connects, although not entirely explicitly, the presence of heresy within responsibility with the history of responsibility. He employs Jan Patočka's differentiation between the responsible and the demonic or orgiastic. The demonic/orgiastic is a state of undifferentiated consciousness, incapable of distinguishing between the self and Other. Responsibility, on the other hand, is born out of self-consciousness and an ability to differentiate. 'A distinction is to be made between the demonic on the other hand (that which confuses the limits among the animal, the human, and the divine...) and responsibility on the other.' (p. 4). However, the demonic is not eliminated through the birth of self-consciousness, but is merely suppressed and incorporated into it:
Although it is incorporated, disciplined, subjugated and enslaved, the orgiastic is not annihilated.... The secret of responsibility would consist in keeping secret, or "incorporated", the secret of the demonic, thus protecting within itself a nucleus of irresponsibility or of absolute unconsciousness (p. 20-22).

This demonic 'nucleus of irresponsibility' contained within responsibility is linked with the theme of silence in Derrida's writing as absence of differentiation can only be experienced outside language or other knowledge systems. The demonic makes its existence, however suppressed, known through the aporias in responsibility.

The demonic brings me to the Fool archetype. The Fool is a symbol of undifferentiated consciousness and, as a figure that is also aporetic in nature, embodies many 
(but not all) dimensions of Derrida's and Levinas's responsibility. As such, the Fool is an appropriate metaphor though which to translate the ethics of Derrida and Levinas into a lived experience. I start by very briefly discussing how archetypes serve to translate abstract notions into concrete experiences. I then turn to the Fool, examining her features, considering how her agency changes when she is embedded within an organisational hierarchy, and explaining her embodiment of responsibility. Finally, I bring the strings of the argument together by discussing the aporias that the Fool reveals in responsible relational leadership.

\section{Archetypes as sensemaking devices}

In (grossly simplified) Jungian psychology, archetypes are indirect manifestations of primordial ideas and abstract themes that constitute the human collective unconscious and appear in dreams and myths, manifested in a variety of images (Carr, 2002). Collective unconscious is a 'deeper layer' of the unconscious that 'does not derive from personal experience ... but is inborn [and] more or less the same everywhere and in all individuals' (Jung, 1972: 3-4). It is a universal and innate human biologically determined psychological makeup that shapes how people experience the world and themselves in it (Campbell, 1991).

Archetypes are motifs and images that aggregate the elements of the collective unconscious (Jacobi, 1959). They represent basic life experiences such as childhood, marriage, maturity, life in society and death, and appear in myths and folk stories that are designed to socialise individuals, reconcile them with their own personal journeys through time and guide their behaviour and cognition (Campbell, 1991, 1992; Stevens, 1982). While the details of archetypal images and stories can be specific to individual societies, their broad forms are universal - the Mother, the Wise Old Man, the Hero, the Crone, the Maiden. One of their number is the Trickster or the Fool. 
There is a small but nonetheless substantial body of research that uses Jung's writings on archetypes to study organisational life (Czarniawska-Joerges and Wolff, 1991; Denhardt, 1981; Mitroff, 1983, a, b; Mrotek, 2001). Particularly prominent over the last few decades is the work of Martin Bowles, Paul Moxnes, Monika Kostera and Jerzy Kociatkewicz. Bowles $(1990,1993,1994,1997)$ refers to archetypes as part of the 'deep structures' (1990: 460) of the collective human psyche that inform activity and understanding within organisations. Individuals enact particular archetypal roles or interpret organisational activity using archetypal images such as marriage and war. As archetypes possess both positive and negative aspects (e.g. Wise Old Woman - Evil Witch), using them as analytical frames helps achieve a more complex and multi-faceted understanding of organisational roles and activities. Paul Moxnes develops the 'deep role' perspective that uses archetypes and myths to explore group dynamics (1999a, 1999b, 2013) and organisational outcomes (Moxnes and Moxnes, 2016). Kociatkiewicz and Kostera (e.g. 2010; 2015, also see Ciuk and Kostera, 2010) used abstract archetypal images such as the oblivion, the labyrinth and the shadow to uncover complexities in organisational identities and experiences. Kostera (2008: 1) argues archetypes 'can help us see and understand many important phenomena that are invisible to the rational instrumental mind'. They reveal hidden aspects of self and the environment, translate abstract concepts into more concrete experiences, and galvanise the imagination (Hart and Brady, 2005; Kociatkewicz and Kostera, 2012).

Archetypal images - e.g. the King or the Hero - have been used to study organisational leadership actors (Ford, Harding and Learmonth, 2008; Kociatkewicz and Kostera, 2012). A Hero is particularly tempting as a metaphor for ethics. However, a Hero, although often capable of doing good, mainly reflects and supports rather than transgresses the existing social order. He may kill the dragon and defeat the usurper, but he does not as a rule challenge the fundamental social structures. The heroic trials are thus often interpreted as 
teaching a person how to deal with immature aspects of the self and find a proper place in the world (Campbell, 1993). As a consequence, I suggest that the Hero may not be the best metaphor for responsibility that implies transgressing prevailing practices. As Derrida (2008: 79) remarks about Abraham: 'Whereas the tragic hero is great, admired, and legendary from generation to generation, Abraham, in remaining faithful to this singular love for the wholly other, is never considered a hero.' Instead, I suggest that it is the Fool who best embodies Levinasian and Derridian responsibility.

\section{Responsibility in Fools}

The Fool, the Trickster, the Jester, the Joker, the Clown are all associated archetypal images (e.g. Dionigi, 2016; Harris, 2012; Nichols, 1974). Each possesses peculiar features, such as the Trickster's inclination towards deceit ${ }^{2}$ and the Jester's towards the critique of power. All, however, have a degree of foolishness or affect, cognition and behaviour that is not considered logical or meaningful in a socially accepted sense. For instance, Jung (1969) labelled his archetype the 'Trickster' ${ }^{3}$, but endowed her with undoubtedly foolish characteristics: he describes the Trickster as a 'simpleton' who is regularly 'fooled' (p. 255). I focus on the figure of the Fool specifically because foolishness (or unconventional rationality) is a common denominator for a collection of characters - Tricksters, Jesters, Clowns and Thieves - whose role is to challenge the existing idea of normality.

On one hand, there are significant divergences between the Fool and my understanding of responsibility. The Fool is an 'archetypal psychic structure of extreme antiquity' that represents 'an absolutely undifferentiated human consciousness' (Jung, 1969: 260). As an undifferentiated being, she is not cognisant of cause and effect, self and other,

\footnotetext{
${ }^{2}$ The Trickster is also associated with the character of the Thief (Brown, 1990).

${ }^{3}$ It is possible that Jung chose the 'Trickster' label because his major source for the discussion of this archetypal figure was Paul Radin's account of the Winnebago stories that involve a trickster character (e.g. Radin, 1976/1956).
} 
light and dark, male and female; she cannot distinguish good from evil, or even herself from her environment. She often does not care about the consequences of her own actions. The undifferentiated nature makes the Fool the personification of Patočka's demonic and is in conflict with Levinas's and Derrida's responsibility that is experienced as a differentiation between self and Other and also as internal strife (Derridad, 2008; Levinas, 1985a). While the responsible person is focused on the needs of the Other, the Fool is often motivated by her own amusement.

On the other hand, it is precisely the Fool's undifferentiated character and her not being tied into any particular knowledge system that allows her to accomplish much that can be called responsible. It is difficult to ignore that in numerous tales the Fool 'manages to achieve through his stupidity what others fail to accomplish through their best efforts' (Jung, 1969: 255). She is the source of exuberant creativity that benefits others around her. In Hindu mythology, trickster god Shiva is a creator and transformer of the world. Norse trickster Loki spends much of his time assisting the gods, including by extracting valuable treasures from the dwarves for the gods (von Schnurbein, 2000). North American trickster Wakdjunkaga protects people from monsters and provides them with valuable tools (Babcock-Abrahams, 1975).

Fool's creativity is a result of her undifferentiated and transgressive nature. As a preconscious being, the Fool is not governed by social norms. Her disregard for convention allows her to attain unexpected and illuminating insights. The Fool- and Trickster-type folk tale characters - such as Nasreddin Hodja - are thus often associated with unconventional wisdom (Kostera, 2012). Robin Hood provides protection for the dispossessed and fights against oppressive social order (Kostera, 2012). Court Jesters and Clowns speak unpalatable truths to kings and hold up mirrors to society's shortcomings through ridicule and the grotesque (Amoore and Hall, 2013; Otto, 2001). Nonsensical riddles are used in some 
Buddhist practices to induce revelations, and mental illness sufferers as seen as Holy Fools close to god in some Christian traditions (Phan, 2001). Arrangements of unmanaged contexts termed 'technology of foolishness' have been seen by some as a way to promote creativity in organisation (Izak, 2013: 87).

The link between the Fool's transgressive nature and her productive creativity is in strong congruence with the responsibility ethics of Levinas and Derrida that cannot be exercised by following convention. As responsibility is about engagement with the infinite alterity of the Other that leads to unchartered territories, the Fool's creativity stems from her freedom to question, to ridicule and to abandon established norms. Her undifferentiated nature allows her to see past the existing meaning categories to alternative realities where the liberation of the oppressed and the overturning of injustice may be possible.

The Fool also personifies the fluid self that is a consequence of being prepared to answer the call of the Other. In the tales, she a habitual shape-shifter, assuming the forms of different animals and moving with ease between sexes (Babcock-Abrahams, 1975). She lacks a stable position in the world. In a Tarot deck, the Fool is the only card without an assigned place within the card hierarchy. Fools and Tricksters are associated with liminal spaces such as crossroads and marketplaces and often violate spatial and temporal boundaries by being active at night, living in secluded caves or wondering the world (Babcock-Abrahams, 1975). The world of the Fool is continuously shifting. Similarly, responsibility is about constant readiness to change oneself in response to the Other. To act responsibly, one cannot hold onto a constant identity or a reified understanding of the world.

Another strong theme in the Fool's character is danger. Her exuberant creativity appears alongside destructiveness (Russo, 2008). Her infantile and unsocialised nature renders her potentially very destructive, and some authors interpret the Fool primarily as a source of danger (e.g. Horvath, 2008). For instance, Loki stands against the gods in the final battle of 
the end of world (von Schnurbein, 2000). Wakdjunkaga desecrates sacred tribal offices and commits acts of mindless cruelty (Babcock-Abrahams, 1975). Shiva, in addition to being the creator, is also the destroyer.

Fool's destructiveness is a poignant illustration of Derrida's assertion that striving for responsibility also opens one up to irresponsibility. Responding to the Other without being able to forecast the outcomes (or playing without aim), abandoning attempts at controlling own position, identity and future (or shape-shifting) is dangerous. The Fool demonstrates the full extent of possible destruction, down to death and the end of the known world.

Place Figure 1 about here

Importantly, the two aspects of the Fool described here - destructiveness and creativity - are not discreet. Both are consequences of her undifferentiated character, and one does not exist without the other. A potent portrayal of this enmeshment of good and evil and the resulting ambiguity is the Fool's representation in the Tarot card decks. The Rider-Waite Tarot deck shows her (Figure 1) as a dreamy young man who is not looking at the path he walks and is about to step over a precipice. However, the sun of divine wisdom is shown to shine on him behind his back and in his hand he holds a rose - a symbol of divine insight. These symbols indicate that the step off the precipice may not lead to his destruction but result in some other consequence that cannot be revealed through conventional understanding (Nichols, 1980).

It is also the Fool's liminal existence in the boundary spaces that generates her creative insight. She does not belong to society, is not held down by established knowledge systems and thus has the opportunity to view them from the outside and challenge them. This parallels the theme of silence and secrecy in Derrida's ethics. The Fool possesses a certain 
loneliness, she stands apart, just as Abraham is alone in his decision to obey god's command.

Having established a connection between the responsibility and the Fool, I now turn to

King Lear for the brief exploration of a Fool in a hierarchical organisational context and

finally to the discussion of how the Fool helps conceptualise and advance the possibility of responsible leadership.

\section{The Fool within a hierarchy}

The literature on how works of fiction reflect, legitimise and interpret organisational and economic realities is well established (De Cock and Land, 2006). Fiction has been a source of ideas and interpretations that, when transposed onto accounts of organisational and social phenomena, can be used to achieve their more complex and critical understandings (Land and Śliwa, 2009; Matanle, McCann and Ashmore, 2008; Śliwa and Cairns, 2007), educate managers (Czarniawska-Joerges and de Monthoux, 1994; Martin, Edwards and Sayers, 2018) and imagine alternative organisational futures (Land and Corbett, 2003; McCabe, 2013; Pick, 2017). I will use Shakespeare's King Lear to develop an understanding of how the Fool, in the incarnation of a Court Jester, may function within a social hierarchy (CzarniawskaJoerges and Wolff, 1991). King Lear, as a great work of literature, possesses complexity necessary to portray the Jester as a character who is as rich and multi-dimensional as her mythical counterpart. It is also a work familiar to many, so I may be excused for only providing a brief summary of the $\operatorname{plot}^{4}$ (please see footnote four, I used the 1963 Signet

\footnotetext{
${ }^{4}$ Having reached an advanced age and wanting to lay down his burdens, King Lear decides to divide his kingdom between this three daughters. He declares that he will award the biggest portion to the one who loves him the most. Two older daughters, Goneril and Regan, are eloquent in flattering their father and so receive their share. The third, Cordelia, although she loves her father dearly, refuses to participate in the farce and is banished. She weds the king of France and leaves Britain. Once Lear abdicates, Goneril and Regan refuse to uphold their promise to maintain their father and his retinue in their households. The dispossessed Lear ends up wondering the wilderness accompanied by his Fool, increasingly sliding into madness, but helped by two loyal subjects who assist him in disguise. Conflicts develop between Goneril and Regan while Cordelia lands in Britain with a French army,
} 
Classic edition).

The message of King Lear in regards to the Fool is that in the officially sanctioned character of the Court Jester the Fool loses much of her generative power. At the first glance, the Jester's position of a critical voice sanctioned by authority is what gives him the opportunity to exercise his ethical function. The Fool is the only person in the story who can speak the truth to Lear with relative impunity. All other individuals loyal to Lear either have to aid the king indirectly, under the cover of false identities, or are banished like Cordelia. Only the Fool accompanies the king under his true identity (if a Fool can be said to have one), and openly criticises the king's decisions.

Lear's Fool also continues the theme of being set apart, which he is in both language and dress. His council to the king does not consist of direct and rational explanations. Instead, it comes in the form of jokes, verses and riddles that can be interpreted in more than one way and thus give the other characters in the play and the audience an opportunity to meditate and consider a variety of angles and implications.

Ultimately, however, the Fool is powerless to change Lear's course and save him from destruction. This arguably happens because, as the Court Jester, he ceases to be an independently functioning being and his influence is always conditioned by his relationship to the king. He exists under the king's protection. His riddles and motley may set him apart, but they are also his only means of speaking to power. He becomes fixed in these characteristics. He can offer critique, but only while existing within the boundaries of the court, much as the

intending to invade and possibly restore Lear to his throne. The French side loses the ensuing battle and Cordelia and Lear are captured. Cordelia is executed despite the fact that the quarrels between Goneril and Regan also result in their deaths. Lear dies of exhaustion and grief. The Fool accompanies Lear throughout the story, intermittently criticising his decisions, pitying him, offering a commentary on the events and providing a degree of support, but always remaining subservient. At the end, the Fool perishes together with Lear, but the circumstances of his death/disappearance are not clear. 
carnival clowns may mock authority only at designated times of the year. The Jester has little power to act but through the king. When embedded into a social hierarchy, the Fool gains a captive audience but loses the power to act upon the world. The dependence of the Fool on the king is underscored when the Fool apparently ${ }^{5}$ meets his death as Lear rapidly approaches his own.

\section{Fools and the possibility of responsible leadership}

What lessons can we derive from the figure of the Fool about the possibility of responsibility in leadership? The Fool exposes the tension between the notion of leadership as constituted through a network of organisational relationships and the notion of responsible leadership defined through the focus on the needs of Others. The potential of responsible relational leadership is problematic precisely because of its relational nature.

As a partial embodiment of Levinasian and Derridian ethics, the Fool concretises the meaning of Derrida's argument that an ethical decision is not possible if it is grounded in an existing and accepted knowledge (Derrida, 2008: 26). Scholars of Levinasian and Derridian ethics (e.g. Bevan and Corvellec, 2007; Painter-Morland, 2010) already note that organisational tools such as codes of conduct constitute such existing knowledges that threaten the possibility of an ethical decision. The Fool adds to this line of thinking by demonstrating that not only specific management tools but also the organisational relational structures form the knowledge systems that can limit the ethical imagination and the possibility of a response to the Other that is not framed around the self. The Fool exercises her

\footnotetext{
${ }^{5}$ In the last act of the play, after Cordelia is treacherously killed, Lear exclaims, 'And my poor fool is hanged'. The word 'fool' can be interpreted in two ways, the first being a term of endearment used by Lear to refer to his daughter. The second possibility refers to the Fool himself, who disappears from the scene some time before and does not enter the play again. It has been suggested (e.g. Stroup 1961) that both Cordelia and the Fool were originally supposed to be played by the same actor, as was a common practice in Shakespeare's times. Thus, Lear's enigmatic utterance could be a game of words that refers to this fact, as well as to the spiritual affinity between Cordelia and the Fool.
} 
creativity while always being set apart from the rest of society. It is by standing outside dominant knowledge systems that she has the power to critique them and put forward new perspectives. When she does acquire an official place in society (e.g. as a Court Jester), her power to critique and to effect change diminishes.

Being 'set apart', however, is not possible in relational leadership that is constituted by particular organisational relational systems (Maak, 2007). Even when leadership is not conceptualised from a relational perspective, it can be difficult to talk about leaders as standing outside the relational organisational structures. For instance, Ford and Harding (2011) provide a powerful argument that even 'authentic' leaders who are defined in leadership literature as committed to their own internal set of values in practice are expected to align these internal values with organisational objectives. Therefore, the possibility of responding to the Other, inside or outside the organisation, from the position of standing apart is limited in the context of leadership and relational leadership in particular. Being a part of such self-referential system limits opportunities for transgressing the internal logic of the system, as the Court Jester demonstrates. The Fool exposes the tension within responsible leadership - that it simultaneously involves embeddedness in a system of relations and requires standing outside that system in order to be able to critique it.

The Fool also points to the conventional language as a knowledge that may limit the possibility of responsibility. Derrida associates responsibility with silence. Silence is a way of 'standing apart' as it allows one to escape the knowledge systems constituted by language and formulate a response to the Other that may have been impossible to contemplate from within the meaning schemas made available by a certain language. The Fool, particularly in the form of the Court Jester engages in similar linguistic escapes, but expands their possible forms beyond silence - e.g. to riddles, jokes, rhyming speech. This non-conventional speech is what literally gives the Jester the critical voice; it is a vehicle of critique. The Fool's use of speech, 
albeit in a modified form, offers a possibility of avoiding a complete silence and thus separation from one's community, but the one that still forces creative thinking.

Current writings on relational leadership, however, are at odds with silence and nonconventional speech as they tend to emphasise the importance of effective and sustained communication within relational networks (e.g. Seeger and Ulmer, 2003; Sutherland, Land and Böhm, 2014; Uhl-Bien, 2006). Other leadership scholars associate transparency with responsibility (e.g. De Hoogh and Den Hartog, 2008). Leadership actors are encouraged to be transparent in their actions and communication with their stakeholders. They are invited to engage in 'clarification of expectations and responsibilities so that employees are clear on what is expected from them' (De Hoogh and Den Hartog, 2008: 298). This is at odds with responsibility as the use of an accepted and shared discourse grounds the leadership actor in a particular set of values and assumptions, precluding a radical critique of those assumptions and the openness to the alterity of the Other.

While individuals in organisation can attempt the adoption of non-conventional speech - e.g. Bevan and Corvellec (2007) advocate that managers adopt a language of submission, service and empathy as opposed to the traditional managerial discourse of efficiency and control - it is fraught with difficulties. The nascent literature on the work of corporate responsibility or sustainability managers exposes such frustrations. The researchers in this area pointed out that while responsibility managers may desire to use the language aligned with Bevan and Corvellec's (2007) recommendations to respond to their stakeholders, they are regularly forced to adopt the language of business cost minimisation, profit margins, growth and other commercial concerns to gain legitimacy within their organisations (Visser and Crane 2010; Wright, Nyberg and Grant 2012). A manager who refuses to accept the conventional language in an attempt at responsible leadership may well deny himself/herself organisational legitimacy and the leadership role. Ultimately, a limited discursive repertoire 
focused on organisational survival forecloses wide-reaching critical and creative reflection. For instance, a responsibility manager's job can be focused on maintaining order by controlling for 'non-financial' reputational risks as opposed to uncovering the violence of existing organisational practices.

In addition to uncovering the tension between the notions of relational and responsible leadership, the Fool challenges the understanding of responsible leadership as an endeavour that delivers positive outcomes. Levinas's and Derrida's understanding of responsibility precludes certainty about the nature of the outcomes of the response. It also preludes any expectation of a return, positive or otherwise. Responsibility is inherently dangerous as it involves making decision on a basis of incomplete information. The Fool demonstrates the possible extent of the danger and its enmeshment with creative vision. Her creativity is grounded in destruction of existing norms, the undermining of the existing order and the absence of a coherent self. The Fool reveals that creativity and destruction are not just two sides of the same coin between which one could choose, but are enmeshed, with one arising out of the other.

Thus, understanding responsible leadership as a purely positively productive activity is problematic. Some authors already note that individuals in leadership positions experience leadership as an anxiety-filled process (e.g. Ford, 2010; Parker, 2004). Striving for responsibility may also not generate positive returns for an individual or an organisation but, on the contrary, mean reduced profits accompanied by the discomfort of organisational change for organisational members. For instance, organisations regularly find responding to the demands of their stakeholders costly when their competitors do not follow suit and such responsiveness has not yet become a norm or, in Derrida's view has not yet transitioned to being non-ethical (Zadek, 2004). Responsibility is dangerous and it becomes safe only when it becomes a norm, in other words, when it ceases to be responsibility. It is conditioned upon 
openness to destructive change. Nonetheless, it is important to note that unlike the story of Abraham, the Fool explicitly offers hope as her activities are not always destructive but often result in positive gains.

To summarise, the Fool archetype embodies many features of Levinas's and Derrida's responsibility and reveals responsible leadership as a problematic notion by shedding light on the aporia situated in it. While leadership is relational, responsibility can only be approached through stepping outside relational structures and language systems that sustain them, potentially severing relationship ties that make up the leadership. The danger and uncertainty involved in the exercise of responsibility also mean that responsible leadership can be attempted only through openness to irresponsibility.

\section{Responsible leadership as experience of aporia}

In this section, I discuss the possible productive implications of the aporia where responsible leadership is characterised by a lack of both leadership and responsibility. Derrida suggest viewing the aporia not as a limit at which the possibility of something stops to the extent that it should not be attempted, but as a limit to see through. The act of seeing through the limit is an act of imagination where the impossible is imagined and thus given the power to shape thoughts and actions. Recognition of an aporia is a moment of rupture where the impossible is glimpsed through the limit and is possibilised:

Derrida ... urges us to think on the impossible, and notes that ' $[\mathrm{t}] \mathrm{o}$ do the impossible cannot be an ethics and yet it is the condition of ethics. I try to think the possibility of the impossible.' For Derrida, 'possibility' and 'impossibility' are not modal opposites' rather, the impossibility of ethics serves as the condition for its very possibility. (Woermann, 2013: 67) 
Aporia of responsible leadership is not to be ignored or suppressed but embraced. 'We must act, even though our actions are imperfect' (Woermann, 2013: 121). Responsibility should be attempted even with the knowledge that it cannot be fully accomplished. The aporia is not a limit at which to stop. Instead, leadership actors should cultivate awareness of and learn to think 'according to the aporia' (Raffoul, 2008: 272).

The Fool's characteristics illuminating the impossibility of responsible leadership also indicate where and how leadership actors can seek out opportunities to partially disengage themselves from the knowledge systems in which we are embedded. Such disengagement will allow them to experience different perspectives, critically reflect upon own knowledge systems, and envisage change. The Fool shows that opportunities for partial disengagement can be found in a variety of liminal situations. Liminality is an ambiguous state of being 'in between': between social roles, between spaces with a clear designated function, or at the margins of established social structures (Garsten, 1999; Tempest and Starkey, 2004) The Fool is able to exercise most of her creative powers when existing in liminal spaces - not separated but not integrated into the society either - on the boundaries, crossroads, marketplaces. Her transgressive capacity is associated with a lack of differentiation or a defined and stable identity. Her creativity is also expressed through play, including playful speech - a liminal 'as if' activity (Statler et al., 2009). Once the Fool acquires a defined place and identity within a social hierarchy, she struggles to effect change.

Similarly, some management scholars identify liminality with opportunities for acquiring novel perspectives, enhancing creativity and challenging established norms. Spaces without clearly designated functions on the margins of workplaces such as corridors, basements, storage rooms, back rooms, etc. offer employees the chance temporarily and at least partially to escape the management gaze, speak more freely and plot challenges to established organisational practices (Courpasson et al., 2017; Shortt, 2015). Liminality 
characterises temporary, transitional or marginal roles such as employees on temporary contracts, freelancers or consultants (Czarniawska and Mazza, 2003; Sturdy et al., 2006; Tempest and Starkey, 2004). Gemmill and Oakley (1992) go as far as call consultants 'sagefools' (p. 122). Authors note that liminal roles facilitate experimenting with a variety of new behaviours, 'heightened noticing' of diverse and new meanings, and self-questioning and self-change (Beech, 2011: 289; Tempest and Starkey, 2004). Finally, play opens up opportunities to imagine and try out different roles, identities, meanings and situations. Through play, established beliefs can be de-naturalised, suspended, displaced, and examined anew (Conroy, 2004; Izak, 2014; Mainemelis and Ronson, 2006; Statler et al., 2009).

Liminality can be a way to act according to the aporia of responsible leadership precisely because it does not involve a complete break with established social systems, but only the stepping onto the margin or the space 'in between'. It is a partial disengagement from current relational structures that creates a critical distance and lets in experiences of the Other while maintaining some links with the old. An encounter with the Other can be attempted without the complete dissolution of the leadership role. Liminal experiences could be sought out through engaging with stakeholders who are not normally part of the organisational circle, participating in events that may not have a direct relevance to the bottom line, purposefully cultivating doubt about the desirability of current practices, temporarily shape-shifting by relinquishing leadership roles or trying out different roles within the relational network, and using unconventional speech. The search for authenticity, on the contrary, as an attempt to reify oneself in a set of well-defined virtues, stands in opposition to liminality and therefore emerges as contradictory to responsibility. Hawkins and Edwards (2013) see doubt as generative and treat leaders who doubt their own authenticity as examples of strong leadership. Weick (2012: 263) argues that good leadership often emanates from 'dropping the heavy tools of logic and rationality'. 
It should not be forgotten, however, that liminality is laced with dangers. One may become lost without the guidance of stable values. The Fool emphasises the necessity to accept the potentially destructive side of liminality, not least through the powerful image of the precipice. Negotiating a diversity of social boundaries and the contradictions of different meanings can be unsettling and painful (Sturdy et al., 2006). Beech (2011) argues that prolonged existence in a liminal state may lead to feelings of anxiety, vulnerability, loss of identity and social isolation. Parker (2004) provides an illuminating account of anxieties experienced by someone who continuously asks questions as opposed to attempting to ground himself/herself in certainties. The Fool, however, and her connection to destruction in the broadest sense (e.g. Loki's role in the end of the world) illuminates the danger of liminality that goes beyond individual negative outcomes and potentially concerns the effects on broader social structures such as organisations.

Embracing aporia of responsible leadership also means accepting the blurring of the of the 'leader' and 'leadership' as concepts that denote a particular positions or activities. The closer I try to focus the attention on the 'responsibility' part of 'responsible leadership' the less meaningful and tangible the 'leadership' part becomes. Leadership dissolves in the movement towards responsibility. As individuals seek out liminal contexts where they may enhance their potential for creative insight and find less reductionist positions from which to respond to the Other, they may have to abandon the relationship structures that enable the exercise of their leadership. This thread of thought provides support to the critical writings that see leader identity as an unattainable goal and organisational members having fluid rather than fixed identities that constantly flow between leader and follower subject positions (e.g. Ford, 2006; Ford et al., 2008; Nyberg and Sveningsson, 2014). It also connects with Gemmill and Oakley's (1992) argument that leaders are socially constructed expressions of the organisational members' desire to control their environment and thus avoid feelings of 
anxiety. Leadership is compromised upon stepping outside relational networks and engaging anxieties in liminal situations.

\section{Conclusion}

In this paper, I aimed to interrogate the conditions of possibility of responsible relational leadership. I defined responsibility using the philosophical perspectives of Emanuel Levinas and Jacques Derrida and then used the archetypal figure of the Fool as a sensemaking device to consider under what conditions responsible leadership may be possible. The Fool allowed me to illuminate responsible relational leadership as an aporia and showed that relational nature of responsible leaderships, while defining it, also presents the key barrier to its realisation. The Fool who contains a possibility of responsibility attains this possibility by walking close to the precipice and occasionally falling off it. Responsibility is conditioned by the readiness to transgress the present norms and values and, without expecting anything in return, answer the call of the Other who can never be fully known. It is possible for the Fool as her nature sets her at least partially apart from any particular system of relationships or knowledge. Organisational leadership, however, is constituted by embeddedness in networks of relationships and knowledge systems which are difficult to transgress from the inside.

However, I also suggested that this aporia should not be treated as a limit where one's journey stops, but as a limit to look beyond, and, through the act of looking, to imagine things different to the current situation. Responsibility may be attempted through seeking out liminal situations that would allow partial disengagement from the relational structures that constitute leadership. Embracing aporia also means acceptance of unintended negative outcomes that is involved in stepping out into the unknown. However, the Fool also offers hope as her transgressions often result in good.

The Fool in both mythology and literature provides an important point of invention 
through which we might imagine conditions under which responsibility can be enacted. She draws attention to the liminality of the ethical moment and the reliance organisational members must place on the possibility of evil in their aspiration towards the good. The Fool reminds us of the impossibility and impracticality of achieving the perfection of ethical leadership and so provides the necessary space of indecision and the dangerous play through which new ethical possibilities for decision and action might emerge. The exposition of the irresolvable tension between ethics and leadership is particularly important in the contemporary anxiety-inducing environment where corporate ethical violations hit the headlines every day and where the temptation to relieve the anxiety through constructing 'responsible leaders' may be great (Gemmill, 2002).

\section{References}

Arjoon S (2000) Virtue theory as a dynamic theory of business. Journal of Business Ethics 28(2): 65-76.

Amoore L and Hall A (2013) The clown at the gates of the camp: Sovereignty, resistance and the figure of the fool. Security Dialogue 44(2): 93-110.

Aronson E (2001) Integrating leadership styles and ethical perspectives. Canadian Journal of Administrative Sciences 18(4): 244-256.

Avolio B, Gardner W, Walumba F, Luthans F and May D (2004) Unlocking the mask: a look at the process by which authentic leaders impact follower attitudes and behaviors. The Leadership Quarterly 15(6): 801-823.

Babcock-Abrahams B (1975) 'A tolerated margin of mess': The Trickster and his tales reconsidered. Journal of the Folklore Institute 11(3): 147-186. 
Bass B and Steidlmeier P (1999) Ethics, character, and authentic transformational leadership behavior. Leadership Quarterly 10(2): 181-217.

Beech N (2011) Liminality and the practices of identity reconstruction. Human Relations 64(2): 285-302.

Bennett N, Wise C, Woods PA and Harvey JA (2003) Distributed leadership. Nottingham: National College of School Leadership.

Bevan D and Corvellec H (2007) The impossibility of corporate ethics: For a Levinasian approach to managerial ethics. Business Ethics: A European Review 16(3): 208-219.

Bolden R (2011) Distributed leadership in organizations: A review of theory and research. International Journal of Management Reviews 13(3): 251-269.

Bondy K (2008) The paradox of power in CSR: A case study on implementation. Journal of Business Ethics 82(2): 307-323.

Bowles M L (1990) Recognizing deep structures in organizations. Organization Studies 11(3): 395-412.

Bowles M L (1993) The gods and goddesses: Personifying social life in the age of organization. Organization Studies 14(3): 395-418.

Bowles M L (1994) Maturation and life in organizations. Organization Studies 15(6): 903 920.

Bowles M L (1997) The myth of management: Direction and failure in contemporary organizations. Human Relations 50(7): 779-803.

Brown ME, Trevino LK and Harrison DA (2005) Ethical leadership: A social learning perspective for construct development and testing. Organizational Behavior and Human Decision Processes 97(2): 117-134.

Brown NO (1990) Hermes the Thief: The Evolution of a Myth. Great Barrington, MA: Lindisfarne Press. 
Campbell J (1991a) The Power of Myth. New York: Anchor Books.

Campbell J (1992) The Masks of God: Primitive Mythology, Volume 1. New York: Arkana.

Campbell J (1993) The Hero with a Thousand Faces. London: Fontana Press.

Carr A (2002) Jung, archetypes and mirroring in organizational change management: Lessons from a longitudinal case study. Journal of Organizational Change Management 15(5) 477-489.

Ciulla JB (2005) The state of leadership ethics and the work that lies before us. Business Ethics: A European Review 14(4): 323-335.

Ciulla JB (2012) Ethics and effectiveness: The nature of good leadership. In: Day DV and Antonakis J (eds) The Nature of Leadership, $2^{\text {nd }}$ ed. Thousand Oaks, CA: Sage, pp.508-540.

Ciuk S and Kostera M (2010) Drinking from the waters of Lethe: A tale of organizational oblivion. Management Learning 41(2): 187-204.

Conroy JC (2004) Betwixt \& Between: The Liminal Imagination, Education, and Democracy. New York: Peter Lang.

Courpasson D, Dany F and Delbridge R (2017) Politics of place: The meaningfulness of resisting places. Human Relations 70(2): 237-259.

Cunliffe AL and Eriksen M (2011) Relational leadership. Human Relations 64(11): 14251449.

Czarniawska B and Mazza C (2003) Consulting as a liminal space. Human relations 56(3): 267-290.

Czarniawska-Joerges B and De Monthoux P (Eds) (2005) Good novels, better management: Reading organizational realities in fiction. Chur, Swizerland: Harwood Academic Publishers.

Czarniawska-Joerges B and Wolff R (1991) Leaders, managers, entrepreneurs on and off the 
organizational stage. Organization studies 12(4): 529-546.

De Cock C and Land C (2006) Organization/literature: Exploring the seam. Organization Studies 27(4): 517-535.

De Hoogh AHB and den Hartog DND (2008) Ethical and despotic leadership, relationships with leader's social responsibility, top management team effectiveness and subordinates' optimism: A multi-method study. The Leadership Quarterly 19(3): 297311.

Derrida J (1993) Aporias (trans. T. Dutoit), Stanford, CA: Stanford University Press.

Derrida J (2008) The Gift of Death, $2^{\text {nd }}$ ed., and Literature in Secret (trans. D. Wills).

Chicago, IL: The University of Chicago Press.

Dionigi A (2016) Personality of clown doctors: An exploratory study. Journal of Individual Differences 37(1): 49-55.

Ford J (2006) Discourses of leadership: Gender, identity and contradiction in a UK public sector organization. Leadership 2(1): 77-99.

Ford J and Harding N (2007) Move over management. We are all leaders now. Management Learning 38(5): 475-493.

Ford J (2010) Studying leadership critically: A psychosocial lens on leadership identities. Leadership 6(1): 47-65.

Ford J and Harding N (2011) The impossibility of the 'true self' of authentic leadership. Leadership 7(4): 463-479.

Ford J, Harding N and Learmonth M (2008) Leadership as Identity: Constructions and Deconstructions. London: Palgrave Macmillan.

Gabriel Y (2004) Myths, Stories and Organizations. Oxford: Oxford University Press.

Gabriel Y (2014) The caring leader-What followers expect of their leaders and why? Leadership 11(3): 316-334. 
Garsten C (1999) Betwixt and between: Temporary employees as liminal subjects in flexible organizations. Organization studies 20(4): 601-617.

Gemmill G (2002) Leadership in the shadow of '9/11'. Ephemera 2(1): 53-60.

Gemmill G and Oakley J (1992) Leadership: an alienating social myth? Human relations 45(2): 113-129.

Gond J-P, Igalens J, Swaen V and El Akremi A (2011) The human resources contribution to responsible leadership: An exploration of the CSR-HR interface. Journal of Business Ethics 98(1): 115-132.

Griffin M, Hymphreys M and Learmonth M (2015) Doing free jazz and free organizations, 'a certain experience of the impossible'? Ornette Coleman encounters Jacques Derrida. Journal of Management Inquiry 24(1): 25-35.

Grojean MW, Resick CJ, Dickson MW and Smith DB (2004) Leaders, values, and organizational climate: Examining leadership strategies for establishing an organizational climate regarding ethics. Journal of business ethics 55(3): 223-241.

Gronn P (2000) Distributed properties: A new architecture for leadership. Educational Management Administration and Leadership 28(3): 317-338.

Harris JM (2012) Smiles of oblivion: Demonic clowns and doomed puppets as fantastic figures of absurdity, chaos, and misanthropy in the writings of Thomas Ligotti. The Journal of Popular Culture 45(6): 1249-1265.

Harris A, Leithwood K, Day C, Sammons P and Hopkins D (2007) Distributed leadership and organizational change: Reviewing the evidence. Journal of Educational Change 8(4): $337-347$.

Hart DW and Brady FN (2005) Spirituality and archetype in organizational life. Business Ethics Quarterly 15(3): 409-428.

Hawkins B and Edwards G (2013) Managing the monsters of doubt: Liminality, threshold 
concepts and leadership learning. Management Learning 46(1): 24-43.

Hibbert P and Cunliffe A (2015) Responsible management: Engaging moral reflexive practice through threshold concepts. Journal of business ethics 127(1): 177-188.

Horvath A (2008) Mythology and the Trickster: Interpreting communism. In: Wöll A and Wydra H (eds) Democracy and Myth in Russia and Eastern Europe. Abingdon: Routledge, pp.27-44.

Izak M (2013) Learning from a fool: Searching for the 'unmanaged' context for radical learning. Management Learning 46(1): 87-104.

Jackson B and Parry K (2011) A Very Short, Fairly Interesting and Reasonably Cheap Book about Studying Leadership, $2^{\text {nd }}$ ed. London: Sage.

Jacobi J (1959) Complex/Archetype/Symbol in the Psychology of C.G. Jung (trans. R. Manheim). London: Routledge/Kegan Paul.

Jones C (2003) As if business ethics were possible, within such limits' . . Organization 10(2): 223-248.

Jones C, Parker M and ten Bos B (2007) For Business Ethics, London: Routledge. Jones J (2014) Leadership lessons from Levinas: Revisiting responsible leadership. Leadership and the Humanities 2(1): 44-63.

Jones SS, Jones OS, Winchester N and Grint K (2016) Putting the discourse to work: On outlining a praxis of democratic leadership development. Management Learning 47(4): 424-442.

Jung CG (1969) On the psychology of the trickster-figure. In: Read H, Fordham M, Adler G and McGuire W (eds) and Hull RFC (trans) The Collected Works, vol. 9, part 1, The Archetypes and the Collective Unconscious, $2^{\text {nd }}$ ed. London: Routledge/Kegan Paul. Jung CG (1972) Four Archetypes: Mother, Rebirth, Spirit, Trickster. London: Routledge. Kociatkewicz J and Kostera M (2010) Experiencing the shadow: Organizational exclusion 
and denial within experience economy. Organization 17(2): 257-282.

Kociatkewicz J and Kostera M (2012) The good manager: An archetypal quest for morally sustainable leadership. Organization Studies 33(7): 861-878.

Kociatkewicz J and Kostera M (2015) Into the labyrinth: Tales of organizational nomadism. Organization Studies 36(1): 55-71.

Kostera M (2008) Introduction to the trilogy: Mythologies of organizational everyday life. In: Kostera M (ed) Organizational Olympians: Heroes and Heroines of Organizational Myths. Houndmills, UK: Palgrave MacMillan, pp.1-2.

Kostera M (2012) Organizations and Archetypes. Cheltenham, UK: Edward Elgar.

Lacan J (1992) The Ethics of Psychoanalysis. 1959-1960. The Seminar of Jacques Lacan. (JA. Miller, Ed., D. Porter, Trans.). London: Routledge.

Land C and Corbett M (2003) From the Borgias to the Borg (and back again). In: Smith W, Higgins M, Parker M and Lightfoot G (eds) Science Fiction and Organization. London: Routledge, pp. 153-169.

Land C and Śliwa M (2009) The novel and organization: introduction from the Editors. Journal of Organizational Change Management 22(4): 349-356.

Levinas E (1978/1997) Otherwise than Being - Or beyond Essence (trans. A. Lingis). Dordrecht: Kluwer.

Levinas E (1985a) Ethics and Infinity: Conversations with Philippe Nemo. Pittsburgh, PA: Duquesne University Press.

Levinas E (1985b) Ethics and Infinity (trans. R. Cohen). Pittsburgh, PA: Duquesne University Press.

Levinas E (1989) Ethics as first philosophy. In Hand S (ed) The Levinas Reader. Oxford: Blackwell, pp.75-88.

Levinas E (2011/1961) Totality and Infinity (trans. A. Lingis). Pittsburg, PA: Duquesne 
University Press.

Maak T and Pless NM (2006) Responsible leadership in a stakeholder society — a relational perspective. Journal of Business Ethics 66(1): 99-115.

Maak T (2007) Responsible leadership, stakeholder engagement, and the emergence of social capital. Journal of Business Ethics 74(4): 329-343.

Mainemelis C and Ronson S (2006) Ideas are born in fields of play: Towards a theory of play and creativity in organizational settings. Research in Organizational Behavior 27: 81131.

Martin L A, Edwards M and Sayers J G (2018) A “Novel” Discovery: Exploring Women’s Literary Fiction for Use in Management and Leadership Education. Academy of Management Learning \& Education 17(1): 24-40.

Matanle P, McCann L and Ashmore D (2008) Men under pressure: representations of the 'salaryman' and his organization in Japanese manga. Organization 15(5): 639-664.

McCabe D (2015) The tyranny of distance: Kafka and the problem of distance in bureaucratic organizations. Organization 22(1): 58-77.

Molyneaux D (2003) 'Blessed are the meek, for they shall inherit the earth': An aspiration applicable to business? Journal of Business Ethics 48(4): 347-363.

Moxnes P (1999a) Deep roles: Twelve primordial roles of mind and organization. Human Relations 52(11): 1427-1444.

Moxnes P (1999b) Understanding roles: A psychodynamic model for role differentiation in groups. Group Dynamics: Theory, Research, and Practice 3(2): 99.

Moxnes P (2013) The Hero's dream and other primordial patterns of imagery: Archetypal influences on organisational fantasies and ideations. Journal of Organizational Change Management 26(4): 638-653.

Moxnes P and Moxnes A (2016) Are We Sucked into Fairy Tale Roles? Role Archetypes in 
Imagination and Organization. Organization Studies 37(10): 1519-1539.

Mrotek D D (2001) The drama of dysfunction: Value conflict in US managed care. Human Relations 54(2): 147-172.

Nichols S (1974) The wisdom of the Fool. Psychological Perspectives 5(2): 97-116.

Nichols S (1980) Jung and Tarot: An Archetypal Journey, York Beach, ME: Red Wheel/Weiser.

Nyberg D and Sveningsson S (2014) Paradoxes of authentic leadership: Leader identity struggles. Leadership 10(4): 437-455.

Ofori G (2009) Ethical leadership: Examining the relationships with full range leadership model, employee outcomes, and organizational culture. Journal of Business Ethics 90(4): 533.

Otto B (2001) Fools are Everywhere: The Court Jester around the World. Chicago: University of Chicago Press.

Painter-Morland M (2010) Questioning corporate codes of ethics. Business Ethics: A European Review 19(3): 265-279.

Parker M (2004) Becoming manager: Or, the werewolf looks anxiously in the mirror, checking for unusual facial hair. Management Learning 35(1): 45-59.

Pearce CL, Wassenaar CL and Manz CC (2014) Is shared leadership the key to responsible leadership? The Academy of Management Perspectives 28(3): 275-288.

Peters TJ and Austin N (1985) A Passion for Excellence: The Leadership Difference. New York: Random House.

Phan PC (2001) The wisdom of holy fools in postmodernity. Theological Studies 62(4): 730 752.

Pick D (2017) Rethinking organization theory: The fold, the rhizome and the seam between organization and the literary. Organization 24(6): 800-818. 
Pless NM and Maak T (2011) Responsible leadership: Pathways to the future. Journal of Business Ethics 98(1): 3-13

Radin P (1976/1956) The Trickster: A Study in American Indian Mythology. New York: Shocken Books.

Raffoul F (2008) Derrida and the ethics of the im-possible. Research in Phenomenology 38(2): 270-290.

Rhodes C (2012) Ethics, alterity and the rationality of leadership justice. Human Relations 65(10): 1311-1331.

Russo J (2008) A Jungian analysis of Homer's ‘Odysseus'. In: Young-Eisendrath P and Dawson T (eds) A Cambridge Companion to Jung. Cambridge: Cambridge University Press.

Seeger MW and Ulmer RR (2003) Explaining Enron communication and responsible leadership. Management Communication Quarterly 17(1): 58-84.

Simpson R, Sturges J and Weight P (2010) Transient, unsettling and creative space: Experiences of liminality through the accounts of Chinese students on a UK-based MBA. Management Learning 41(1): 53-70.

Sims R and Brinkmann J (2003) Enron ethics (or: Culture matters more than codes). Journal of Business Ethics 45(3): 243-256.

Sims R and Brinkmann J (2002) Leaders as role models: The case of John Gutfreund at Solomon Brothers. Journal of Business Ethics 35(4): 327-339.

Sisson AJG (2003) The Moral Capital of Leaders: Why Virtue Matters. Cheltenham, UK: Edward Elgar Publishing.

Śliwa M and Cairns G (2007) The novel as a vehicle for organizational inquiry: Engaging with the complexity of social and organizational commitment. ephemera 7(2): 309325. 
Spillane J and Diamond JB (2007) Distributed Leadership in Practice. New York: Teachers College Press.

Statler M, Roos J and Victor B (2009) Ain't misbehavin': Taking play seriously in organizations. Journal of Change Management 9(1): 87-107.

Stevens A (1982) Archetype. A Natural History of the Self. London: Routledge.

Sturdy A, Schwarz M and Spicer A (2006) Guess who's coming to dinner? Structures and uses of liminality in strategic management consultancy. Human Relations 59(7): 929-60.

Sutherland N, Land C and Böhm S (2014) Anti-leaders(hip) in social movement organizations: the case of autonomous grassroots groups. Organization 21(6): 759781.

Tempest S and Starkey K (2004) The effects of liminality on individual and organizational learning. Organization Studies 25(4): 507-527.

Uhl-Bien M (2006) Relational leadership theory: exploring the social processes of leadership and organizing. Leadership Quarterly 17(6): 654-676.

Van de Ven B (2005) The (im)possibility of a Levinasian business ethics: Towards an interpretation of the ethical in business. Working Paper, Tilburg University, Available at: www2.le.ac.uk/departments/management/documents/research/researchunits/cppe/conference-pdfs/levinas/vandeven.pdf (accessed 29 October 2017).

Visser W and Crane A (2010) Corporate sustainability and the individual: Understanding what drives sustainability professionals as change agents. SSRN Paper Series, Available at: http://papers.ssrn.com/sol3/papers.cfm?abstract_id=1559087 (accessed 29 October 2017).

Von Schnurbeing S (2000) The function of Loki in Snorri Sturluson's 'Edda'. History of Religions 40(2): 109-124.

Wang D, Waldman DA and Zhang Z (2014) A meta-analysis of shared leadership and team 
effectiveness. Journal of Applied Psychology 99(2): 181-198.

Weick K (2012) Making Sense of the Organization, Volume 2: The Impermanent Organization. Chichester, UK: Wiley.

Woermann M (2013) On the (Im)Possibility of Business Ethics: Critical Complexity, Deconstruction, and Implications for Understanding the Ethics of Business. New York: Springer.

Woodruff P (2001) Reverence: Renewing a Forgotten Virtue. New York: Oxford University Press.

Wray-Bliss E (2013) A crisis of leadership: Towards an anti-sovereign ethics of organisation. Business Ethics: A European Review 22(1): 86-101.

Wright C, Nyberg D and Grant D (2012) 'Hippies on the third floor': Climate change, narrative identity and the micro-politics of corporate environmentalism. Organization Studies 33(11): 1451-1475.

Wu LZ, Kwan HK, Yim FHK, Chiu RK and He X (2015) CEO ethical leadership and corporate social responsibility: A moderated mediation model. Journal of Business Ethics 130(4): 819-831.

Zadek S (2004) The path to corporate responsibility. Harvard Business Review 82(12): 125 132. 
Figure 1: The Fool card in the Rider-Waite tarot deck

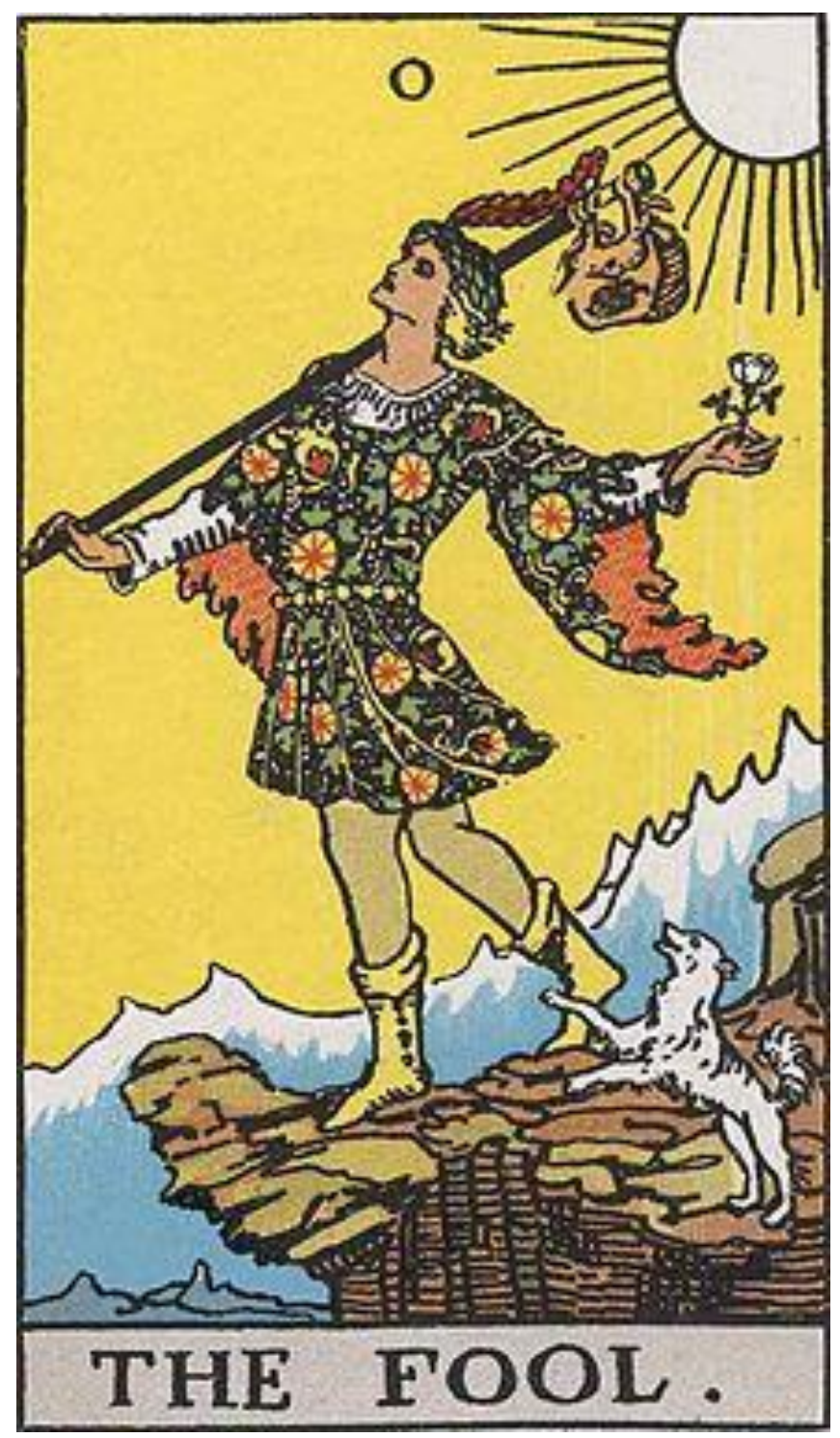

